\title{
Cloning of the cDNA for thyroid stimulating hormone $\beta$ subunit and changes in activity of the pituitary- thyroid axis during silvering of the Japanese eel, Anguilla japonica
}

\author{
Y-S Han, I-C Liao', W-N Tzeng and J Y-L Yu² \\ Institute of Zoology, College of Science, National Taiwan University, Taipei, Taiwan, Republic of China \\ ${ }^{1}$ Taiwan Fisheries Research Institute, 199 Hou-lh Road, Keelung, Taiwan, Republic of China \\ ${ }^{2}$ Endocrinology Laboratory, Institute of Zoology, Academia Sinica, Taipei, Taiwan 115, Republic of China \\ (Requests for offprints should be addressed to J Y-L Yu, Email: johnyu@ccvax.sinica.edu.tw)
}

\begin{abstract}
The purposes of this study were: (1) to clone the cDNA encoding pituitary thyroid-stimulating hormone beta subunit (TSH $\beta$ ) of the Japanese eel, Anguilla japonica, together with its genomic DNA sequence, for phylogenetic analysis, and to study the regulation of the TSH $\beta$ gene expression in cultured pituitaries; and (2) to investigate the transcript levels of pituitary TSH $\beta$ mRNA and the serum thyroxine profiles at different stages of ovarian development before and during silvering in the wild female eels. The maturity of female eels was divided into four stages, juvenile, sub-adult, pre-silver, and silver, based on skin color and oocyte diameter. The genomic DNA of the TSH $\beta$ subunit contains two introns and three exons, and the TSH $\beta$ protein possesses a putative signal peptide of 20 amino acids and a mature peptide of 127 amino acids. The amino acid sequence identities of TSH $\beta$ mature peptide of Japanese eel compared with those of teleosts and other vertebrates are: European eel $(98.4 \%)$, salmonids $(60.6-61.3 \%)$, carps $(52.0-56.7 \%)$, sturgeon $(48.4 \%)$, and tetrapods $(42.9-45.2 \%)$. In in vitro studies of the regulation of TSH $\beta$ mRNA it was found that thyrotropin-releasing hormone increased while thyroxine decreased its expression. RT-PCR and real-time quantitative PCR analysis showed that the transcript levels of TSH $\beta$ subunit increased during eel silvering. The serum thyroxine levels also increased in parallel with TSH $\beta$ mRNA expression during silvering, supporting the hypothesis that the hypothalamus-pituitary-thyroid axis is correlated to silvering in the wild female Japanese eels.
\end{abstract}

Journal of Molecular Endocrinology (2004) 32, 179-194

\section{Introduction}

The pituitary glycoprotein hormones in vertebrates include thyroid-stimulating hormone (thyrotropin, TSH), luteinizing hormone, and follicle-stimulating hormone, each consisting of two different subunits, $\alpha$ and $\beta$ (Pierce \& Parsons 1981). The $\alpha$ subunits are identical in a given species and are common to all pituitary glycoprotein hormones, while the $\beta$ subunits are specific for each hormone and determine the hormonal activity and species specificity. The $\alpha$ and $\beta$ subunits are initially formed as separate proteins by different genes, and following glycosylation they are associated by non-covalent bonding to form biologically active hormonal molecules.

The synthesis and release of TSH is regulated by hypothalamic thyrotropin releasing hormone (TRH) and negative feedback is controlled by the thyroid hormones, triiodothyronine $\left(\mathrm{T}_{3}\right)$ and thyroxine $\left(\mathrm{T}_{4}\right)$; this comprises the hypothalamuspituitary-thyroid (HPT) axis in vertebrates (McNabb 1992, Chatterjee et al. 2001). Thyroid hormones are essential for development, growth, metabolism, behavior, and reproduction in vertebrates (Gorbman et al. 1983). Thyroid hormones 

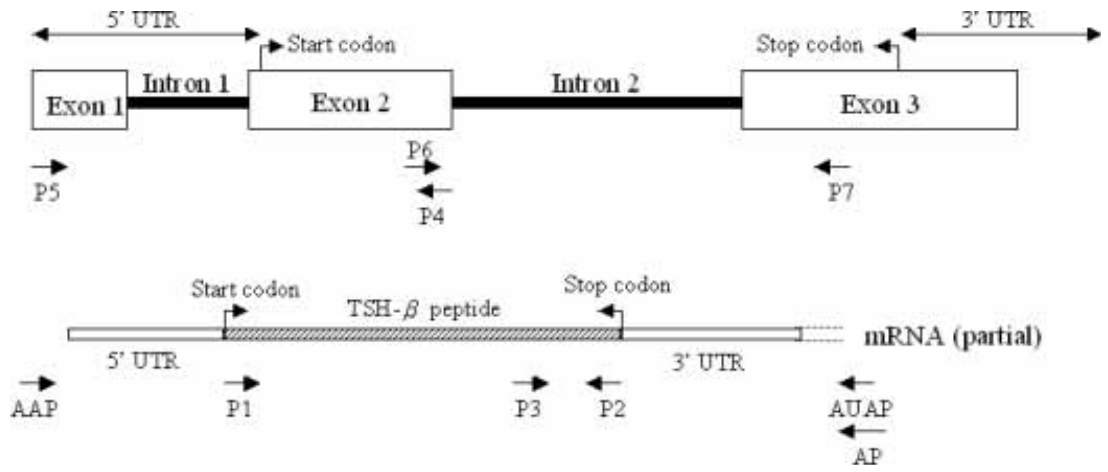

Figure 1 Procedures of RT-PCR sequencing of TSH $\beta$ subunit genomic DNA (upper) and cDNA (lower) from pituitary glands of the Japanese eel. Numbers of primers $(P)$ indicate the corresponding oligonucleotides listed in Materials and methods.

have long been implicated in the migration of anadromous salmonids. They are required for the preparatory transformation of parr to a seawatertolerant smolt, and are thought to stimulate migratory behavior (Boeuf 1994). In juvenile salmonids, there is an indication that thyroid hormones are involved in the body silvering process by depositing guanine in the skin (Ikuta et al. 1985, Ura et al. 1994). In conger eel, Conger myriaster, thyroid hormones are important in the regulation of metamorphosis from the leptocephalus to the elver (Yamano et al. 1991). The HPT axis is also closely correlated to reproduction. A significant temporal relationship exists for most species of teleosts between thyroid status and gonadal status over at least certain phases of the reproductive cycle (Cyr \& Eales 1996). Based on the studies of several teleost species, it was thought that the thyroidal activity usually increases during early gonadal development, is maintained or enhanced during the period of reproduction, and commonly decreases during or after spawning (Cyr \& Eales 1996).

The Japanese eel, Anguilla japonica Temminck and Schlegel, is a catadromous fish with a complex life cycle that includes both marine and freshwater habitats (Tesch 1977). After living in rivers for years, eels undergo pronounced morphological and physiological changes from yellow to silver eels (also known as 'silvering') (Tesch 1977, Lokman \& Young 1998a,b). The modifications include skin color changing from white/yellow to silver on the belly and from green to black on the back, downstream migration behavior, and rapid development of the gonad. Accordingly, the HPT axis may be involved in eel silvering. However, no information is yet available with respect to the corresponding changes in thyroid status during silvering of Japanese eels. We therefore investigated the changes in the pituitary-thyroid axis during silvering of wild Japanese eels. As a direct assay of eel TSH is unavailable as yet, the TSH $\beta$ transcript levels were estimated to represent thyrotropin expression activity from the pituitary. The circulating thyroxine levels were estimated to reflect the thyroid status. Since the genome and peptide sequence of TSH $\beta$ for Japanese eel are not known yet, we also cloned the TSH $\beta$ gene for phylogenetic analysis. We report here the cloning of the genomic and cDNA sequences for Japanese eel TSH $\beta$ and its deduced peptide sequence, the regulation of TSH $\beta$ mRNA expression, and the changes in TSH $\beta$ mRNA expression levels together with circulating thyroxine levels at various stages of ovarian development during silvering of wild female Japanese eels.

\section{Materials and methods}

\section{cDNA cloning of the Japanese eel TSH $\beta$ subunit}

\section{Design of oligonucleotide primers}

Oligonucleotides, used as PCR primers for amplification of the TSH cDNA and genomic DNA of the Japanese eel, are listed below and shown in Fig. 1. The sense primer (SP: $5^{\prime} \rightarrow 3^{\prime}$ ) and antisense primer (ASP: $3^{\prime} \rightarrow 5^{\prime}$ ) were designed from 
the conserved coding region of the TSH $\beta$ cDNA of the European eel and other teleosts. The $\beta$ actin sequence of the Japanese eel was cloned in our laboratory.

Primer 1, SP for TSH $\beta$ subunit: 5'-ATGAGAG TGGTCGTGTTGGCG-3'; primer 2, ASP for TSH $\beta$ subunit: 5'-GGATGTGGTTGGTCTGT CCGGG-3'. Primer 3, SP for 3'-rapid amplification of cDNA ends (RACE): 5'-GATCGGGGG CGGGACGAGTG-3'; primer 4, ASP for 5'RACE: 5'-CGATGGAGATGGTGGTGTTGA3'. Primer 5, SP for TSH $\beta$ subunit: 5'-GACA CTCGGAGAAAATTCTAC-3'; primer 6 , SP for TSH $\beta$ subunit: 5'- CTTGTGGGTGGCGAT CAACACCA-3'; primer 7 , ASP for TSH $\beta$ subunit: 5'-CACTGGTCGGGGGCGGGATC3'. Adapter primer (AP) for 3'-RACE: 5'GGCGACGCGTCGACTAGTACTTTTTTTTT TTTTTTTT-3'. Abridged universal amplification primer (AUAP) for 3'-RACE: 5'-GGCGACGC GTCGACTAGTAC-3'. Abridged anchor primer (AAP) for 5'-RACE: 5'-GGCGACGCGTCGACT AGTACGGG I IGGGI IGGG I IG-3', where I is the base inosine. Primer of SP for $\beta$-actin subunit: 5'-GCTGTCGCTGTATGCCTCTGG-3'; primer of ASP for $\beta$-actin subunit: $5^{\prime}$-GTCAGGATCTT CATGAGGTAGTC-3'.

\section{RT-PCR for TSH $\beta$ CDNA sequence and RACE}

Fresh pituitary glands were collected from the cultured Japanese eels reared in the laboratory. Total RNA was then extracted using the total RNA miniprep system kit (Viogene, Sunnyval, CA, USA). The concentration and quality of the extracted RNA were measured at A260 nm/ A280 nm (Kontron Spectrophotometer, UVIKON 810). Complementary DNA was synthesized using oligo-d $(\mathrm{T})_{18}$ primer $(100 \mathrm{ng})$ and moloney murine leukemia virus-reverse transcriptase (MMLV-RT) (Stratagene, La Jolla, CA, USA) following instructions recommended by the manufacturer. Reverse transcription was performed for $35 \mathrm{~min}$ at $42{ }^{\circ} \mathrm{C}$ and later at $70{ }^{\circ} \mathrm{C}$ for $10 \mathrm{~min}$ to heat-inactivate the MMLV-RT.

The PCR was performed in $50 \mu$ final volume with $2 \cdot 5 \mathrm{U}$ Taq DNA polymerase (Gibco BRL, Gaithersburg, MD, USA) using primers 1 and 2 (100 ng for each). After an initial 3 min denaturing step at $94{ }^{\circ} \mathrm{C}, 35$ cycles of amplification were performed using a cycle profile of $94{ }^{\circ} \mathrm{C}$ for $1 \mathrm{~min}$,
$62{ }^{\circ} \mathrm{C}$ for $40 \mathrm{~s}$, and $72{ }^{\circ} \mathrm{C}$ for $1 \mathrm{~min}$. Elongation was extended to $10 \mathrm{~min}$ at $72{ }^{\circ} \mathrm{C}$ after the last cycle. The PCR products were sequenced commercially with an ABI 377 automated sequencer (PerkinElmer Applied Biosystems).

The remaining $5^{\prime}$ and $3^{\prime}$ untranslated region (UTR) sequences were obtained by RACE using the RACE kit (Gibco BRL). Briefly, $1 \mu \mathrm{g}$ of the pituitary total RNA was reverse-transcribed using primer AP by 200 U Superscript II reverse transcriptase, followed by PCR between primer 3 and the AUAP. For 5'-RACE, $1 \mu \mathrm{g}$ of the pituitary total RNA was first reverse-transcribed by $200 \mathrm{U}$ Superscript II reverse transcriptase with primer 2. The acquired single strand cDNA was column purified and then oligo-dC tailed using terminal deoxynucleotidyl transferase. PCR was then performed using primer 4 and the AAP.

\section{Total DNA extraction and PCR for TSH $\beta$ genomic DNA}

The total genomic DNA of the Japanese eel was extracted from the liver using the total DNA miniprep system kit (Viogene). The TSH $\beta$ genomic DNA sequence was obtained by PCR with primers 5 and 7 , located in the head of the 5 '-UTR and the end position of the coding region of TSH $\beta$ cDNA respectively. Intron sequences were obtained by re-amplifying the PCR product with primers 4 and 5 for intron I and primers 6 and 7 for intron II.

\section{Regulation of TSH $\beta$ mRNA expression}

Cultured Japanese eels $(n=27)$ at the yellow stage, reared in the laboratory for 2 years, were used for studying the regulation of TSH $\beta$ mRNA. Pituitary tissue culture was carried out based on the procedures described by Gregory and Porter (1997) with some modifications. Pituitaries were collected from the Japanese eels, immediately washed twice in $1 \times$ Hanks buffer and placed in $35 \mathrm{~mm}$ culture dishes. Each pituitary was sliced into 4 pieces, incubated in $1.5 \mathrm{ml}$ M-199 (Sigma) containing $25 \mathrm{mM}$ HEPES, $4 \mathrm{mM} \mathrm{NaHCO}, 0 \cdot 1 \% \mathrm{BSA}$ and antibiotics (penicillin and streptomycin), and treated with saline (control group), TRH (pGluHis-Pro- $\left.\mathrm{NH}_{2}, 10^{-8} \mathrm{M}\right)$, or $\mathrm{T}_{4}\left(10^{-8} \mathrm{M}\right)$. All the dishes were kept in a $\mathrm{CO}_{2}$ incubator maintained under $3.5 \% \mathrm{CO}_{2}$ concentration at $30{ }^{\circ} \mathrm{C}$ for $6 \mathrm{~h}$. After centrifugation, the total RNAs were isolated 
Table 1 Morphometric characteristics of the wild Japanese eels in different stages of ovarian development

\begin{tabular}{|c|c|c|c|c|c|}
\hline & \multicolumn{2}{|l|}{ Yellow } & Pre-silver & Silver & Tukey's HSD \\
\hline Time of collection & $\begin{array}{l}\text { Dec. } 2000 \\
\text { Feb. } 2003\end{array}$ & $\begin{array}{l}\text { Aug., Oct. } 2000 \\
\text { Feb. } 2001\end{array}$ & $\begin{array}{l}\text { Oct. } 2000 \\
\text { Jun } 2001\end{array}$ & $\begin{array}{l}\text { Oct., Dec. } 2000 \\
\text { Feb, } 2001\end{array}$ & \\
\hline Total length (cm) & $43 \cdot 4 \pm 1 \cdot 0$ & $53 \cdot 7 \pm 1 \cdot 3$ & $60 \cdot 7 \pm 1 \cdot 6$ & $65 \cdot 1 \pm 2 \cdot 0$ & $\mathrm{Ju}<\mathrm{Sa}<\mathrm{Ps}=\mathrm{Sv}$ \\
\hline Oocyte diameter ( $\mu \mathrm{m})$ & $40 \cdot 0 \pm 0.95$ & $73 \cdot 8 \pm 2 \cdot 5$ & $109 \cdot 4 \pm 3 \cdot 4$ & $181 \cdot 1 \pm 12 \cdot 2$ & $\mathrm{Ju}<\mathrm{Sa}<\mathrm{Ps}<\mathrm{Sv}$ \\
\hline Digestosomatic index & $1 \cdot 81 \pm 0.09$ & $1 \cdot 71 \pm 0 \cdot 10$ & $1 \cdot 35 \pm 0.08$ & $0.47 \pm 0.08$ & $\mathrm{Ju}=\mathrm{Sa}>\mathrm{Ps}>\mathrm{Sv}$ \\
\hline
\end{tabular}

Ju, juvenile; Sa, sub-adult; Ps, pre-silver; Sv, silver. $P<0.05$ for all significance differences.

from the tissues. The RNA was reverse transcribed as described and the cDNA was PGR amplified using TSH $\beta$ primers 1 and 7. As an internal control in the RT-PCR reactions, $\beta$ actin was also amplified simultaneously for normalization. An optimal PGR amplification cycle (25 cycles) was chosen to observe the different cDNA levels based on parallelism of different PCR cycles $(15,20,25$, and 30 cycles). PCR products were analyzed by $2.5 \%$ agarose gel electrophoresis. To validate the mRNA levels estimated by RT-PCR analysis, two samples of each treatment were tested for real-time quantitative PCR using the fluorescence dye SYBR Green 1 (Morrison et al. 1998).

\section{Transcript levels of TSH $\beta$ mRNA at different stages of ovarian development of wild female Japanese eels}

\section{Collection of wild eels and classification of maturing status}

Wild female Japanese eels $(n=46)$ were collected by eel traps in the estuary of the Kaoping River in southwest Taiwan $\left(120^{\circ} 50^{\prime} \mathrm{E}\right.$ and $22^{\circ} 40^{\prime} \mathrm{N}$ ) (Table 1). Males were difficult to collect because the sex ratio was skewed to females (Tzeng et al. 2002); thus, only females were considered in this study. These eel samples have previously been used for investigation of gonadotropin mRNA transcript levels (Han et al. 2003a). The eels were stunned by ice before morphometric measurement. Total length (TL, $\pm 0.1 \mathrm{~cm}$ ) and body weight (BW, $\pm 0 \cdot 1 \mathrm{~g})$ of the eels were measured before decapitation for blood collection. The sex of each eel was determined by histology of the gonad. The gonad weight $(\mathrm{GW}, \pm 0.01 \mathrm{~g})$ and digestive tract weight (DW, $\pm 0.01 \mathrm{~g}$ ) were measured and the gonadosomatic index (GSI) and digestosomatic index (DSI) were estimated according to the formulae, $\quad \mathrm{GSI}=100 \times[\mathrm{GW}(\mathrm{g}) / \mathrm{BW}(\mathrm{g})]$ and $\mathrm{DSI}=100 \times[\mathrm{DW}(\mathrm{g}) / \mathrm{BW}(\mathrm{g})]$ respectively. Oocyte diameters $(\mathrm{OD}, \pm 1 \mu \mathrm{m})$ were calculated according to Yamamoto et al. (1974).

In our previous investigation, the maturity of the wild female Japanese eels before and during silvering were divided into three stages (yellow, pre-silver and silver) based on skin color and histological observations of ovarian development (Han et al. 2003b). In the present study, the yellow eels were further divided into juvenile and sub-adult stages based on OD for better comparison (Table 1). The GSI and OD of the female Japanese eel were significantly different among different ovarian developmental stages $(P<0 \cdot 05$, Table 1). Ovaries of juvenile eels contained mainly stage II (chromatin nucleolus stage) oocytes $(<50 \mu \mathrm{m})$. The ovaries of sub-adult eels also contained stage II (chromatin nucleolus stage) oocytes predominantly, but with larger OD (50-90 $\mu \mathrm{m})$ (Table 1). In the pre-silver eels, the oocytes $(90-130 \mu \mathrm{m})$ grew rapidly and were mainly in stage III (peri-nucleolus stage). The initial oil drops became apparent at the periphery of the oocytes. In the silver eels, the oocytes $(>130 \mu \mathrm{m})$ continued to grow, and the oil drops accumulated and filled the whole cytoplasm. They were mainly in stage IV (oil-drop stage) (Han et al. 2003b). 


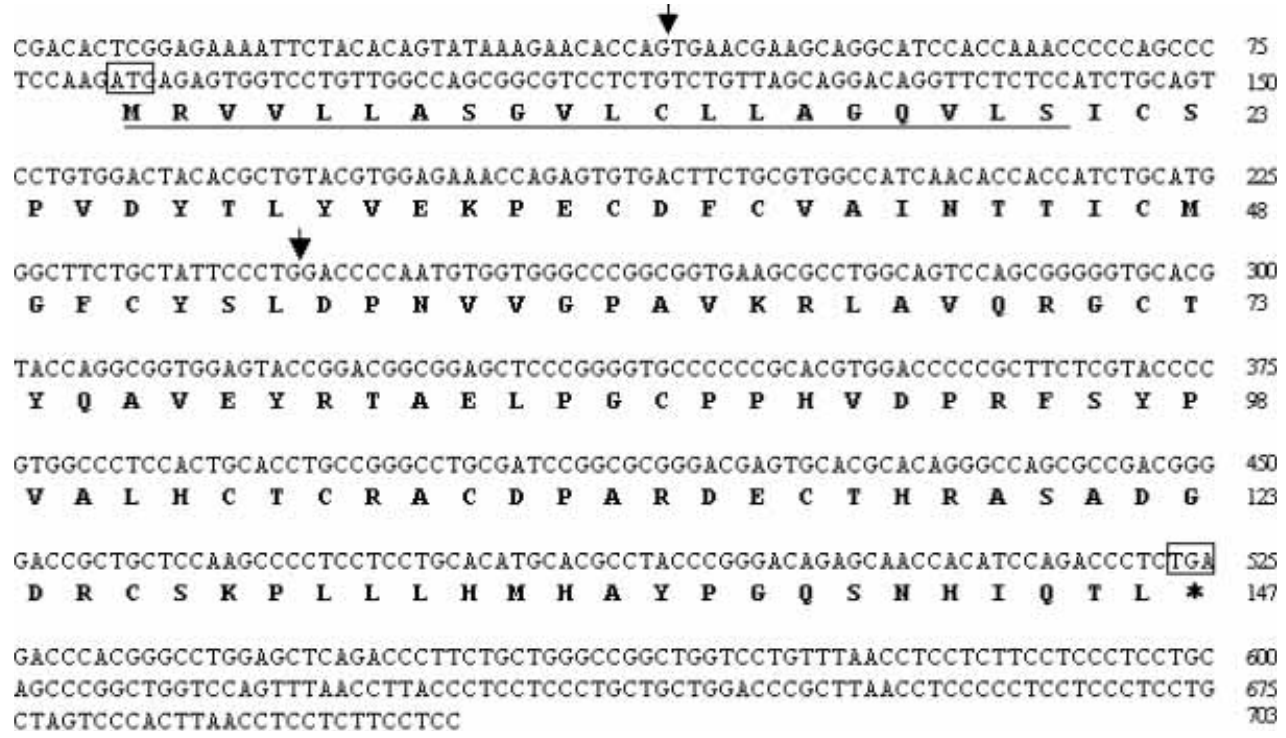

Figure 2 cDNA nucleotide and deduced amino acid sequences of the Japanese eel TSH $\beta$ subunit. In the right-hand column, upper numbers refer to the nucleotide sequence and lower numbers refer to the amino acid sequence. The start (ATG) and stop (TAG, indicated by an asterisk) codons are shown by boxes. The two arrows show, respectively, the introns 1 and 2 insertion sites.

\section{Measurement of pituitary TSH $\beta$ mRNA levels}

Total RNA $(1 \mu \mathrm{g})$ from individual pituitaries of wild female Japanese eels of juvenile $(n=11)$, sub-adult $(n=17)$, pre-silver $(n=9)$, and silver $(n=9)$ stages was reverse-transcribed using oligo-d $(\mathrm{T})_{18}$ primer (100 ng) and MMLV-RT (Stratagene) following instructions recommended by the manufacturer. PCR reactions for TSH $\beta$ were performed using primers 1 and 7 with 25 cycles. As an internal control in the RT-PCR reactions, $\beta$ actin was also amplified simultaneously for normalization. To validate the reliability of RT-PGR analysis, two pituitaries of eels selected from each ovarian stage were analyzed by real-time quantitative PCR as described.

\section{Radioimmunoassay (RIA) of serum thyroxine levels of wild female Japanese eels at different stages of ovarian development}

Measurement of serum thyroxine $\left(\mathrm{T}_{4}\right)$ was performed by commercial kits (Diagnostic System Laboratories, Texas, USA). The cross-reactivity of the $\mathrm{T}_{4}$ antibody was measured for thyroxine $(100 \%)$, triiodothyroacetic acid $(1 \cdot 13 \%)$, triiodothyronine $(0.91 \%)$, diiodothyronine $(0.03 \%)$, and other related hormones which were not detectable. The minimum detection limit was $4 \mathrm{ng} / \mathrm{ml}$ serum. Since the collected blood of juvenile eels was insufficient for RIA analysis, only the other three stages of female Japanese eels were used for serum $\mathrm{T}_{4}$ measurement in the present study.

\section{Statistical analysis}

Differences among the eel stages of the morphometric indexes or the transcript levels of TSH $\beta$ mRNA were analyzed by one-way analysis of variance (ANOVA) followed by Tukey's HSD (Honestly Significantly Different) test. Significance level was considered to be at $P<0 \cdot 05$.

\section{Results}

\section{Sequence analysis of the Japanese eel TSH $\beta$ cDNA and genomic DNA}

The acquired TSH $\beta$ cDNA of Japanese eel was $703 \mathrm{bp}$ in total length, including $81 \mathrm{bp}$ of the 5'-UTR, $444 \mathrm{bp}$ of the coding region, and $178 \mathrm{bp}$ of partial 3'-UTR (Fig. 2). The agarose gel analysis of the PCR products of TSH $\beta$ 3'-RACE showed multiple bands, thus the full $3^{\prime}$-UTR sequence was difficult to obtain. The coding region encodes a putative protein of 147 amino acids, which contains 
CGACACTCGGAGAAATTCTACACAGTATAhAGAACACCAGgtgagegagggecttgtttcatacattgcaccg

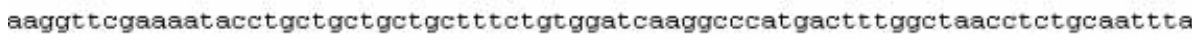
ttcttgcaatgttgttggaaat tgaaagactatgaaccacat tatttgaggcaggagtagatt taggaattt tgtatt gaccaccaataataataat aataataagttgaatagt tgectcaactctaccataaaaacaagtg

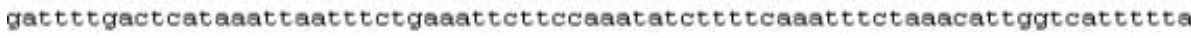
aacat tcaccat tataatt tattataatacagaaactt aaacagtaaaaatcgcacagaaataggtttatgtg getcaacttttttgcacgegtcaagccaaaaatcgttgattgaaaatgtaaaacgtatttatttggtttc ggtgeagTGAACGAAGCAGGCATCCACCAAACCCCCAGCCCTCCAAGTAGAGTGGTCCTGTTGGCCAGCGGC GTCCTCTGTCTGTTAGCAGGACAGGTTCTCTCCATCTGCAGTCCTGTGGACTACACGCTGTACGTGGAGAACC מGAGTGTGACTTCTGCGTGGCCATCA\&CACCACCATCTGCATGGGCTTCTGCT\&TTCCCTGgtaagagectcca gtctgegggecagget getetggeateggcaagt t tcagtggtatacetgagtcaccacctcat gagt gegetc tccttatttcgccattccactgtgttacaccggecaattracagacceaccgattttatttettgtcacacat cacetctgaagagattaacaaatgactetgtctctaatgttagagetttetetttatageatetettect tttgacaggacctaaaaatgtgtgtaaatgcgatgtaatgtaatgtat tgtaatgtagcat tatgtaatgt tac gaaatgtgatgcaatatat gtat gtaatgtaatcaaacgtaacgtaacgtaatgtattccaatgtaatgtaa cgtaacaaaaacaaacataacgaaatcaaacataacgaaaagtaacaaaacgtaacgaaatgaaacataacga aaagtaacaaaacgt aacgtaatgaaacgtaacgaaacgtaacataacgtactgtgatgtaatgtaatgtaacg taatgtat tgtaatataacataacataatgtagcatat gtgatgtaatgtaaagtaacgtaacgtaatgtatt gtaatataacataacgtaatgtagcgtat gtgatgtaatgt aaagtaatgtaacgtaatgtat gtaatataa cataacgtaacataacgtat tgtgatgtaatgtaaagtaacgtaacgtaatgtattgtaatataacataacgta atgtaacgtattgtgatgtaatgtaaagtaacgtaacgtaatgtattgtaatataacataacgtaatgtagege attgtgatgtaatgtattgatteccgetggeaglGCCCChATGTGGTGGGCCCGGCGGTGA GGCCCTGGCAGT CCAGCGGGGGTGCACGTACCAGGCGGTGGAGTACCGGACGGCGGAGCTCCCGGGGTGCCCCCCGCACGTGGACC CCCGCTTCTCGTACCCCGTGGCCCTCCACTGCACCTGCCGGGCCTGCGATCCGGCGCGGGACGAGTGCACGCAC AGGGCCAGCGCCGACGGGGACCGCTGCTCCAAGCCCCTCCTCCTGCACATGCACGCCTACCCGGGACAGAGCAA CCACATCCAGACCCTCTGAGACCCACGGGCCTGGAGCTCAGACCCTTCTGCTGGGCCGGCTGGTCCTGTTTAAC CTCCTCTTCCTCCCTCCTGCAGCCCGGCTGGTCCAGTTTAACCTTACCCTCCTCCCTGCTGCTGGACCCGCTTA aCCTCCССТCCTCCCTCCTGCTAGTCCCACTTAACCTCCTCTTCCTCC

Figure 3 Genomic DNA sequences of the Japanese eel TSH $\beta$. The start codon (ATG), stop codon (TAG), and the ends of introns (gt-ag) are shown by boxes. Intron sequences are shown by the lower-case characters.

a signal peptide of 20 amino acids and a mature peptide of 127 amino acids (Fig. 2).

The genomic DNA sequence of the TSH $\beta$ subunit was PCR amplified by primers 4, 5, 6 and 7 . The acquired sequences were compared with that of the TSH $\beta$ subunit cDNA for identification of the introns (Fig. 3). Two introns were observed; intron 1 was located in the 5'-UTR (Fig. 2), which included 484 bp (Fig. 3) while intron 2 (including 860 bp, Fig. 3) was within the coding region (Fig. 2). Both introns started with a gt base pair and ended with an ag base pair. We only found one form of intron I and II in the TSH $\beta$ genomic DNA as indicated by only one band of PCR product of TSH $\beta$ genomic DNA amplified from primers 5 and 7.

\section{Regulation of the TSH- $\beta$ gene expression}

The experiment on the regulation of mRNA of the TSH $\beta$ showed that TRH at $10^{-8} \mathrm{M}$ significantly increased its expression $(P<0.001)$, while $\mathrm{T}_{4}$ at
$10^{-8} \quad \mathrm{M}$ significantly decreased its expression $(P<0.001)$ (Fig. 4). Representative real-time quantitative PGR for TSH $\beta$ mRNA expressions at different treatments is shown in Fig. 5(A). The calculated expression levels of TSH $\beta$ mRNA estimated by real-time quantitative PGR were comparable to the corresponding mRNA levels estimated by the RT-PCR analysis.

\section{Changes in TSH $\beta$ mRNA expression levels at different ovarian stages of wild Japanese eel}

The expression of TSH $\beta$ mRNA levels at different stages of ovarian development is shown in Fig. 6. The results were normalized with data from densitometric scanning of a constitutively expressed protein $\beta$ actin. As indicated, TSH $\beta$ mRNA levels gradually increased with ovarian development $\left(\mathrm{F}=3 \cdot 12>\mathrm{F}_{(0 \cdot 05,26)}=3 \cdot 03, P=0 \cdot 048\right)$, and the differences were significant between silver and juvenile/sub-adult stages $(P<0 \cdot 05)$. Representative 
(A)

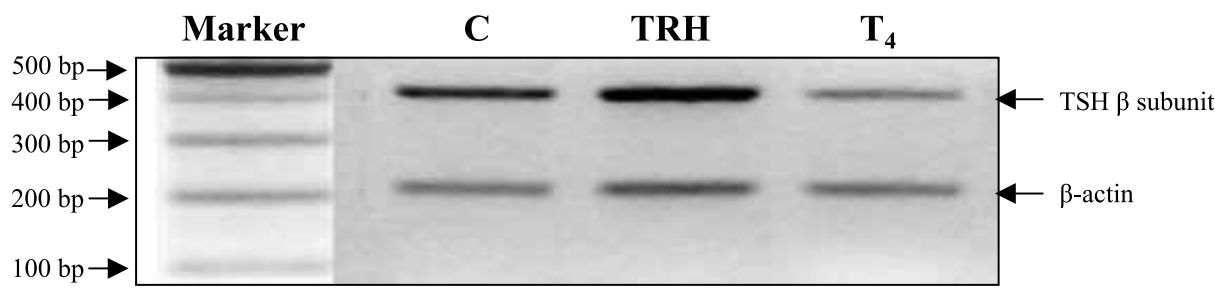

(B)

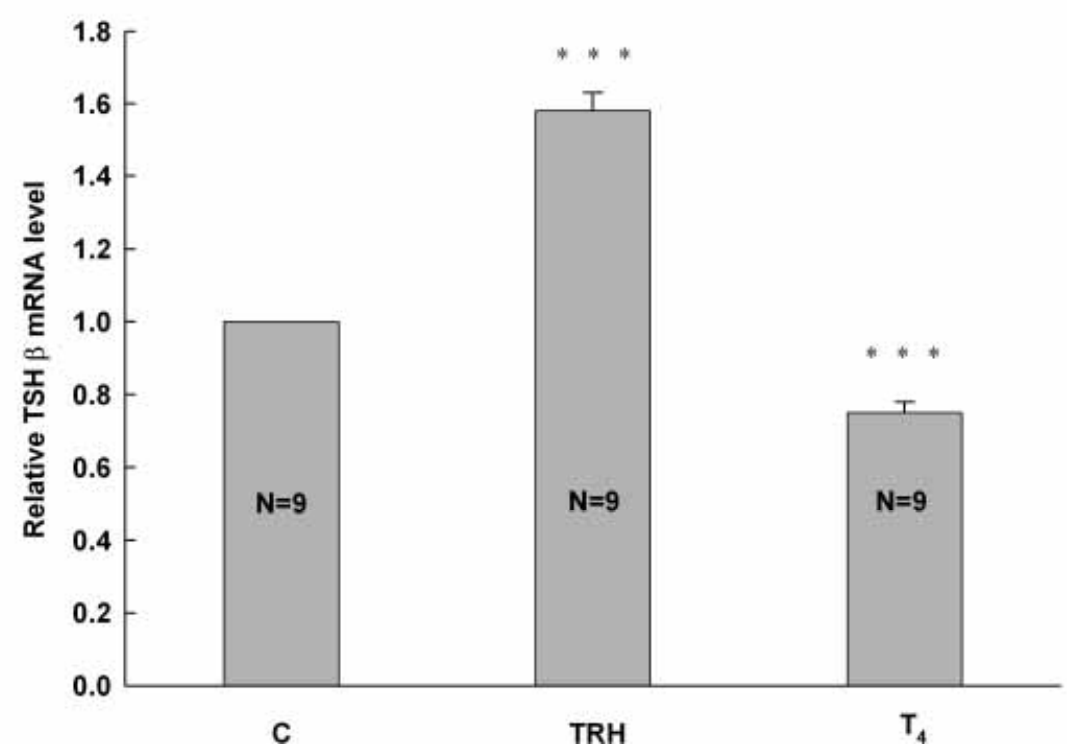

Figure 4 Regulation of TSH $\beta$ mRNA expression of the cultured Japanese eel pituitaries by TRH and $T_{4}$. (A) Total RNA extracted from each treatment was reverse transcribed and subjected to PCR. Amplified products were analyzed on $2.5 \%$ agarose gel. $\beta$ actin was used as a control in each column. C, control. (B) The band intensities of TSH $\beta$ subunits in different treatments were analyzed by Kodak Digital Science ID image analysis software (ver 3.0). The value of the control group was considered as 1 and the values of the other groups were calculated with respect to the control group. $N$ indicates the eel numbers. ${ }^{\star \star \star} P<0.001$, significant difference compared with control (C).

real-time quantitative PGR for TSH $\beta$ mRNA expressions at different stages of ovarian development is shown in Fig. 5(B). The calculated mRNA levels of TSH $\beta$ mRNA expression at different ovarian stages estimated by real-time quantitative PCR were comparable to the corresponding mRNA levels estimated by the RT-PCR analysis. 
(A)

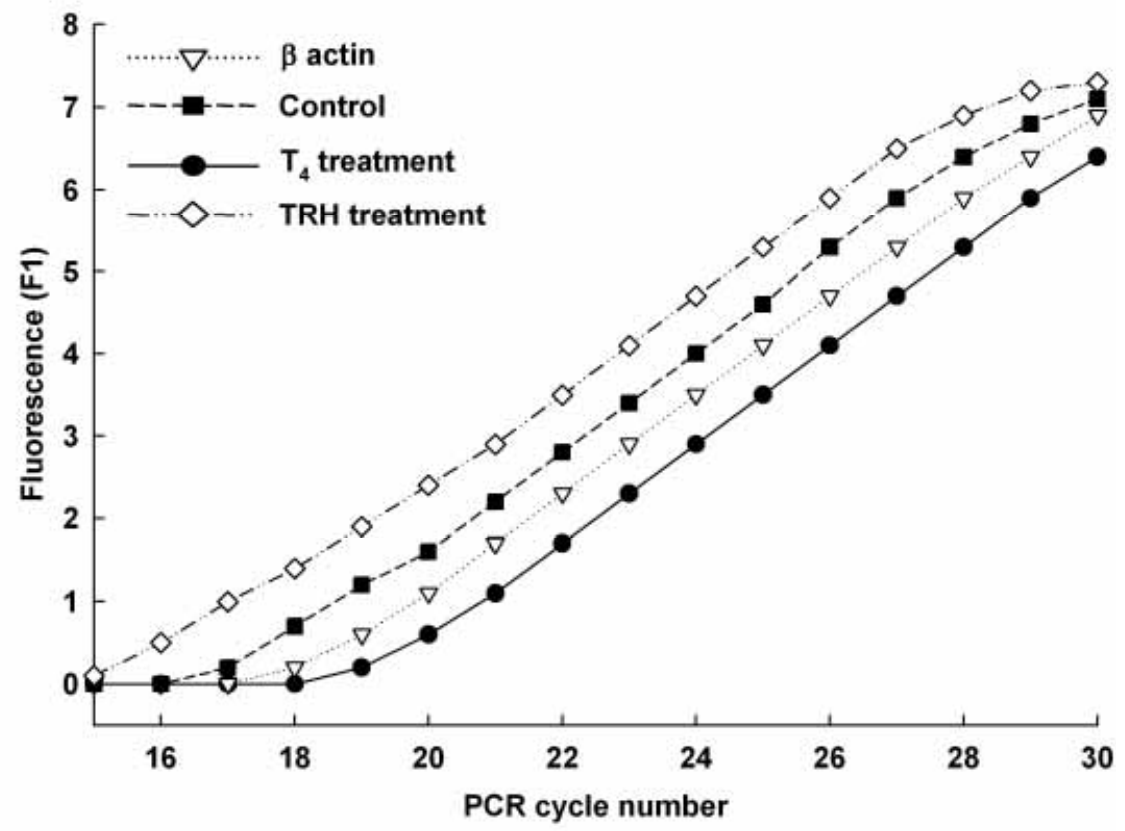

(B)

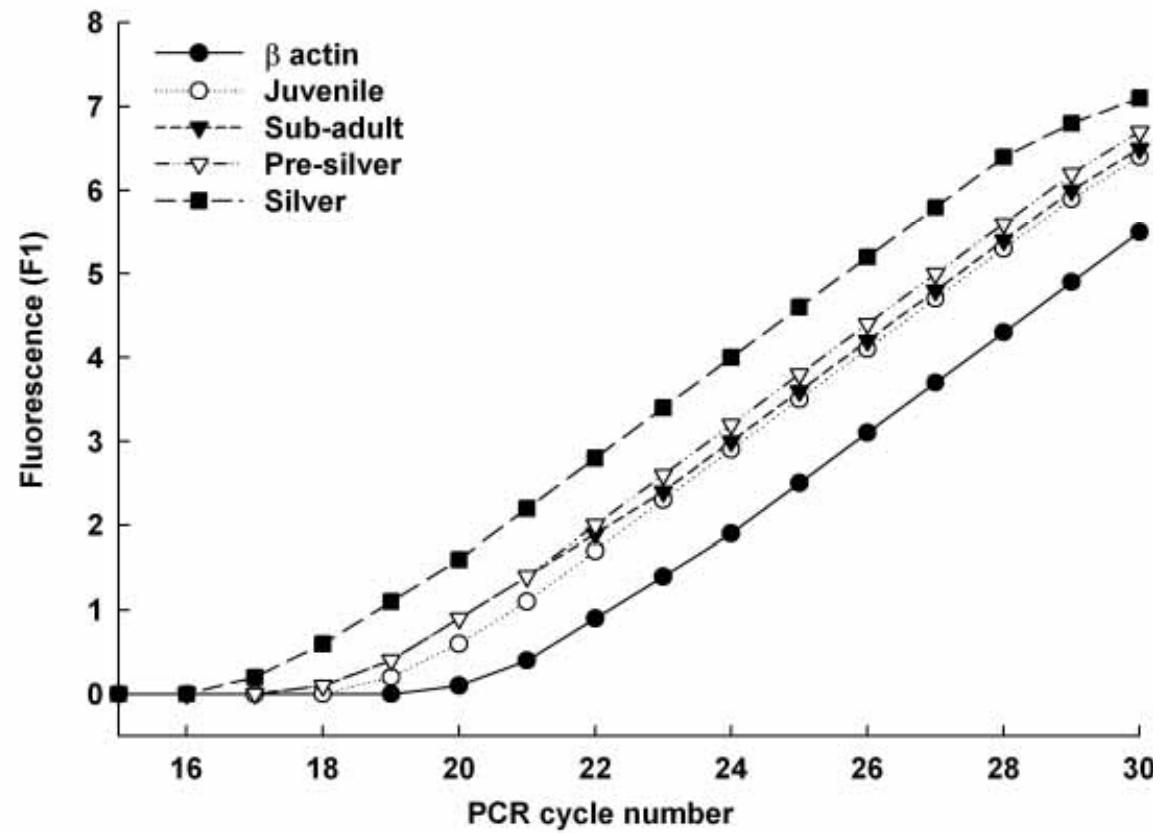

Figure 5 Representative real-time quantitative PCR of TSH $\beta$ mRNA expressions for Japanese eels following (A) $\beta$ actin, control, TRH, or $\mathrm{T}_{4}$ treatments and (B) at different stages of ovarian development in wild female Japanese eels. 
(A)

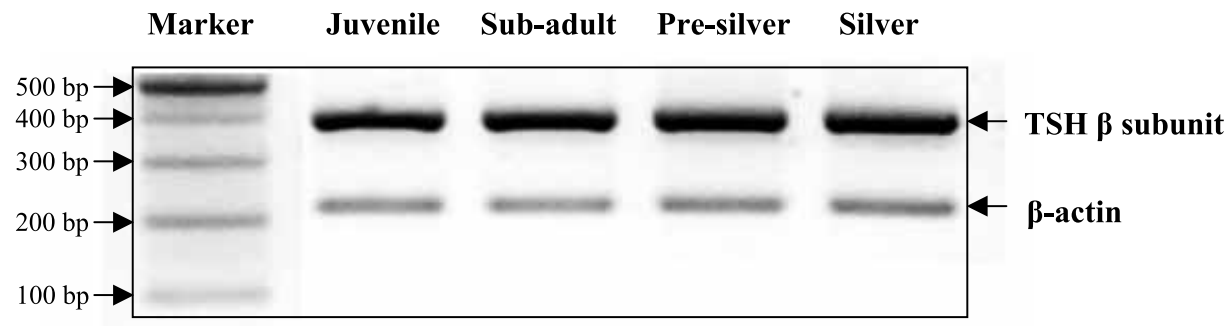

(B)

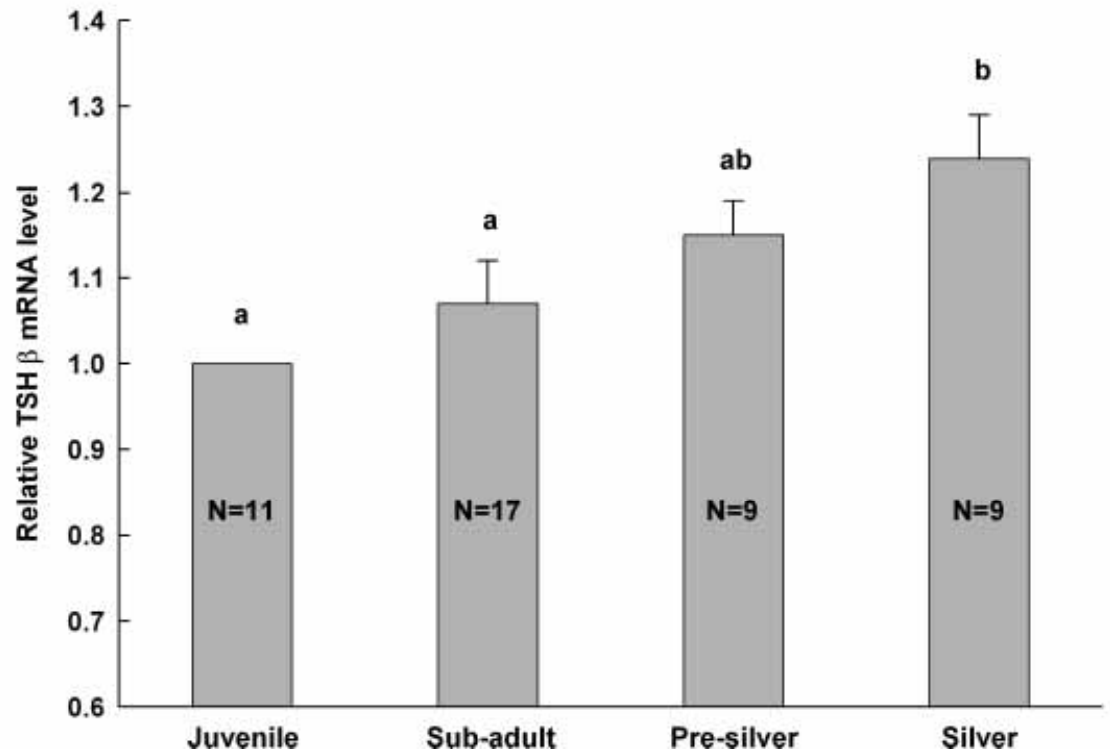

Figure 6 Expression of the TSH $\beta$ subunit mRNA in the wild female Japanese eel pituitaries at different stages of ovarian development. (A) Total RNA preparation and agarose gel analysis were the same as in Fig. 4. $\beta$ actin was used as a control in each column. (B) The band intensities of $\beta$ subunits from juvenile, sub-adult, pre-silver, and silver stages. The value of the juvenile group was considered as 1 and values of other stages were calculated with respect to the juvenile group. Different letters above the bars indicate that the differences are statistically significant $(P<0.05)$. Numbers inside the bars represent sample size.

\section{Serum thyroxine levels at different ovarian stages of wild Japanese eel}

Mean serum $\mathrm{T}_{4}$ levels gradually increased during eel silvering, with $9 \cdot 17 \pm 0.92 \mathrm{ng} / \mathrm{ml}$ in sub-adult,
$12.01 \pm 1.53 \mathrm{ng} / \mathrm{ml}$ in pre-silver, and $14.96 \pm$ $1.57 \mathrm{ng} / \mathrm{ml}$ in silver females respectively. Significant differences were found among eel stages $\left.\left(\mathrm{F}=5 \cdot 61>\mathrm{F}_{(0.05,}, 34\right)=3.29, \quad P<0.01\right), \quad$ and the 


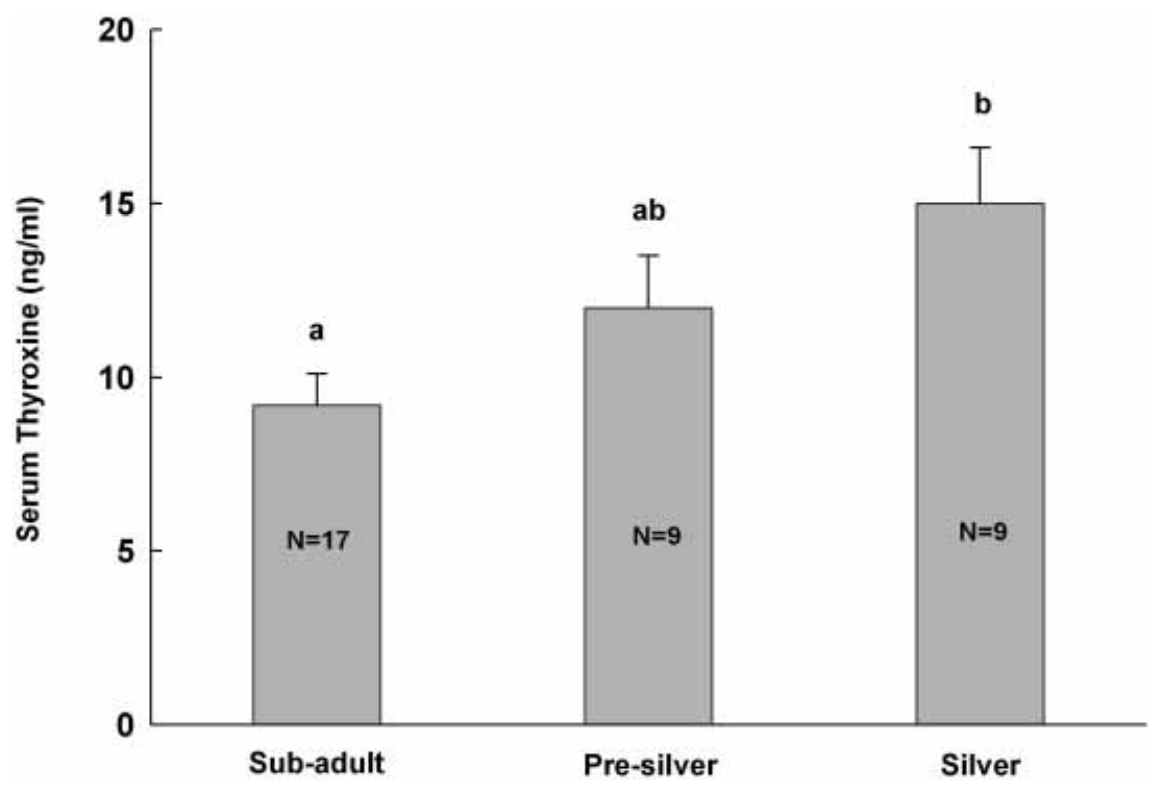

Figure 7 Serum thyroxine levels at different ovarian stages of the wild female Japanese eels. Different letters above the bars indicate that the differences are statistically significant $(P<0.05)$. Numbers inside the bars represent sample size.

differences were significant between silver females and sub-adult female eels $(P<0 \cdot 05)$ (Fig. 7).

\section{Discussion}

Comparisons of protein sequences of Japanese eel TSH $\beta$ with teleosts and other vertebrates are shown in Fig. 8. As indicated, positions of all 12 cysteine residues, forming six-disulfide bonds within the $\beta$ subunits, and one asparagine-linked glycosylation site between cysteine 3 and 4 , are conserved in all vertebrates. Differences of two amino acids in the mature peptide of TSH $\beta$ are observed between Japanese eel and European eel (98.4\% of identity) while a one amino acid difference exists in the signal peptide between the two eels (95\% of identity) (Table 2 and Fig. 8). The amino acid identities of TSH $\beta$ mature peptide of Japanese eel compared with teleostean species from other orders range from $48.4 \%$ to $61 \cdot 3 \%$, and compared with tetrapods they range from $42 \cdot 9$ to $45 \cdot 2 \%$ (Table 2). Such findings demonstrate that a high degree of diversity exists in the TSH $\beta$ peptide sequence among different teleostean orders, and between teleosts and tetrapods, indicating the low degree of conservation of the TSH $\beta$ amino acid sequence in vertebrates during evolution. The results also indicate that the intra-order homology of TSH $\beta$ (ex. Japanese eel vs European eel) is greater than the homology of inter-order (ex. anguillids vs salmonids), which in turn is greater than the homology of inter-animal class (ex. teleosts vs mammals). The phylogenetic tree of amino acid sequences of TSH $\beta$ mature peptides of the vertebrates, constructed by the Neighbor-Joining method, indicates that TSH $\beta$ subunits from different species of the same animal class are grouped together in accordance with the known phylogenetic orders (Fig. 9). As indicated, the Chondrostean sturgeon is closer to the tetrapods than the teleosts; such findings are similar to the results reported by Quérat et al. (2000).

The sequence identity of TSH $\beta$ signal peptide for Japanese eel is high in comparison with European eel (95\%), but below $40 \%$ when compared with other species (Table 2). It is interesting to note that the percentage identities of TSH $\beta$ signal peptide between Japanese eel and other vertebrates are always lower than the corresponding identities of TSH $\beta$ mature peptide (Table 2), indicating that the signal peptide is less conserved than the mature peptide of TSH $\beta$ during evolution. On the other hand, the genetic structure of TSH $\beta$ of the Japanese eel contains 


Japanese eel
European eel
Atlantic salmon
Rainbow trout
Common carp
Bighead carp
Goldfish
Siberian sturgeon
Rat
Human
Chicken
Duck
Toad

Japanese eel
European eel
Atlantic salmon
Rainbow trout
Common carp
Bighead carp
Goldfish
Siberian sturgeon
Rat
Hunan
Chicken
Duck
Toad

$-20 * * * * * *$

MRVVLLASGVLCLLAGQVLSICS PVDYTLYVEKPECDECVAINTTICMGECYSLDPNVVG 40

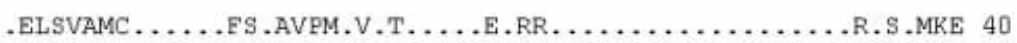

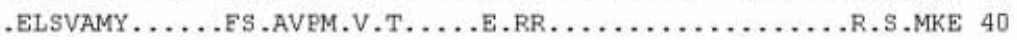
.SP-VYVV.M.GI.MKVAMPM.A.TE..I.I.RQ.NY ..V.......E.R.S.KE 39 .SP-.YVV.M.G. MKIAAPM.A.TE..I.I.RQ..NY...V.........R.S..KE 39 .SP-VYVV.M.GI.MKVAMPM.A.TE..I.I.RQ..NY...V........E.R.S..KE 39 .SAAV.TCAL ...AM.NAS.L.E.TA.........AY............VTR.V.LKS 40 .NAVV.F.VLFA.ACE..S.F.I.TE.MM. DRR . AY.LT. . . . A.Y.MTR.I.GKL 40 .TALE.M.MLEG.TC .AM.F.I.TE..MHI.RR..AY.LT.....A.Y.MTR.I.GKL 40 .SPEFMM.LLFG.TE . TA.V.A.SE..IH...R.AY.L......A...MTR.S.GKK 40 .SPFEVM.LLEG.TE. .TA.L.A.SE. .IH. .R. .AY.L..........MTR.S.GKK 40 ---GT.LLF.MAI. .AV.V.FLTE. .M. .......AY.L..........MTK...LKE 35 PAVKRLAVQRGCTYQAVEYRTAEL PGCP PHVDPRESYPVALHCTCRACDPARDECTHRAS 100

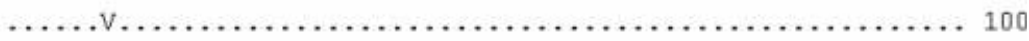
L.GP.ELI.....DQ.....VI.......AN.L.T.......H.GT.NTDS ...A.K. 100 L.GP.ELI......DQ....VI.......AN.L.T.......H.GT.NTDS ...A.K.. 100

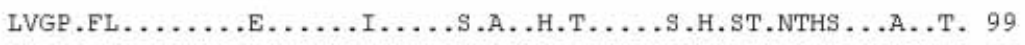
LVGP.EL................... SYA..H.T..... S.H.ST.NTHS .....KT. 99 LVGA.FL......HE...M.I.....S.A.H.I....S.H.ST.NTNS ...A.KTN 99 LLP.SALS.SS . . .DLSYH.VT. . . . L.SN.SY..A. .MS.R..K.NTDYS . .MEPL 100 FLP.YALS.DV...RDET...V.I....H.A.Y........K.GK.NTDYSD ...E.V 100 FLP.YALS.DV...RDFI...V.I.......A.Y.........K.GK.NTDYSD.I.E.I 100 LLL.SALS.NV...KEME.Q..LI....H.TI.YY....IS.K.GK.NTDYSD.V.EKC 100 LLL.SALS.NV ...KEML.Q..LI.....HHTI.YY ....IS.K.GK.NTDYSD.V.EKC 100 GLP.M.MS.KA.S.KEYIH. .VTI. ...MH.N.L . . . IS.E.DK.NTGETD.IQDTI 95

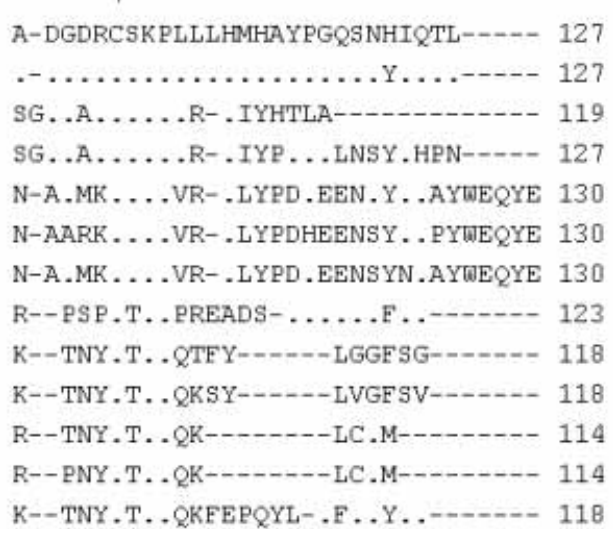

Figure 8 A comparison of the amino acid sequence of TSH $\beta$ of the Japanese eel with other species. The species and their accession numbers of the GenBank or published papers are: Japanese eel (Anguilla japonica, AY158008), European eel (Anguilla anguilla, Paradet-Balade et al. 1998), Atlantic salmon (Salmo salar, 073824), rainbow trout (Oncorhynchus mykiss, Ito et al. 1993), common carp (Cyprinus carpio, BAA20082), bighead carp (Aristichthys nobilis, Chatterjee et al. 2001), goldfish (Carassius auratus, Sohn et al. 1999), Siberian sturgeon (Acipenser baerii, Quérat et al. 2000), rat (Rattus norvegicus, Carr et al. 1987), human (Homo sapiens, Hayashizaki et al. 1985), chicken (Gallus gallus, Gregory \& Porter 1997), duck (Cairina moschata, Hsieh et al. 2000), toad (Xenopus laevis, Buckbinder \& Brown 1993). The signal peptide sequence is underlined. The dots represent amino acids that are identical to Japanese eel, and the dashes are included to improve the alignment. The twelve conserved cysteine residues are denoted by asterisks, and the one asparagine-linked glycosylation site is denoted by a cross. 
Table 2 Comparison of percentage identity of signal and mature TSH $\beta$ peptides between Japanese eel and other vertebrates

\begin{tabular}{|c|c|c|}
\hline \multicolumn{3}{|l|}{ Species* } \\
\hline Japanese eel & $100 \cdot 0$ & $100 \cdot 0$ \\
\hline European eel & $95 \cdot 0$ & $98 \cdot 4$ \\
\hline Atlantic salmon & $35 \cdot 0$ & $61 \cdot 3$ \\
\hline Rainbow trout & $35 \cdot 0$ & $60 \cdot 6$ \\
\hline Common carp & $21 \cdot 1$ & $56 \cdot 7$ \\
\hline Bighead carp & 31.6 & $52 \cdot 8$ \\
\hline Goldfish & $21 \cdot 1$ & $52 \cdot 0$ \\
\hline Siberian sturgeon & $35 \cdot 0$ & $48 \cdot 4$ \\
\hline Toad & 33.3 & $45 \cdot 2$ \\
\hline Chicken & $30 \cdot 0$ & $44 \cdot 3$ \\
\hline Duck & $30 \cdot 0$ & $44 \cdot 3$ \\
\hline Rat & $40 \cdot 0$ & 43.7 \\
\hline Human & $35 \cdot 0$ & 42.9 \\
\hline
\end{tabular}

*The accession numbers of the GenBank and references are indicated in the legend of Fig. 8.

three exons and two introns, the same as the rat (Carr et al. 1987), goldfish (Sohn et al. 1999), and European eel (Paradet-Balade et al. 1998). The positions of intron I are all located in the 5'-UTR, and the insertion sites of intron II are all located within the coding region of the comparable positions. The length and nucleotide sequence of the corresponding introns are highly variable among vertebrates. For example, the lengths of intron II in the Japanese eel, European eel, goldfish and rat are 860, 533/681, 299 and $377 \mathrm{bp}$ respectively, indicating their low conservation among vertebrates.

Previous study in European eel shows that there is only one copy of the TSH $\beta$ gene in each individual but with multiple forms of alleles, and the polymorphism of TSH $\beta$ occurring in the regions of intron II and $3^{\prime}-\mathrm{UTR}$ is due to the different numbers of minisatellites (Paradet-Balade et al. 1998). Therefore, heterogeneities of TSH $\beta$ mRNA in length among individual eels were detected by Northern blot analysis (Paradet-Balade et al. 1997, 1998). In the present study, the multiple bands of the 3 '-RACE PCR product of TSH $\beta$ cDNA in the Japanese eels may be due to the heterogeneity of $3^{\prime}$-UTR, as in the case of the European eel. We also observed that the single cDNA band amplified from the coding region of TSH $\beta$, obtained by RT-PGR analysis from the present study, should facilitate the quantification of
TSH $\beta$ mRNA as compared with the single or double bands of TSH $\beta$ mRNA with various lengths obtained by Northern blot analysis.

$\mathrm{TRH}$ is a major hypothalamic simulating hormone for the secretion of pituitary TSH in mammals (Prasad 1985). In the teleosts, the presence of immunoreactive TRH has been found in common carp (Hamano et al. 1990), sea bass (Batten et al. 1990), and chinook salmon (Matz \& Takahashi 1994). Recently, the stimulatory effect of TRH on the TSH $\beta$ mRNA expression has been reported in bighead carp (Chatterjee et al. 2001). In the present study, TRH was also found to increase the level of TSH $\beta$ mRNA (Fig. 4). In contrast, thyroid hormones have been shown to directly depress TSH $\beta$ mRNA levels from pituitaries under in vitro cultured conditions of various tetrapods (Croyl \& Maurer 1984, McNabb 1992, Hsieh et al. 2000) and teleosts (Pradet-Balade et al. 1997, Chatterjee et al. 2001). In the present study, we also demonstrated that $\mathrm{T}_{4}$ depressed TSH $\beta$ mRNA expression in the pituitary culture of Japanese eel (Fig. 4). As indicated, a rather modest response of the TSH $\beta$ mRNA expression was obtained in the present study; incubation of the Japanese eel pituitary fragments with $\mathrm{TRH}$ and $\mathrm{T}_{4}$ at $10^{-8} \mathrm{M}$ for $6 \mathrm{~h}$ at $30{ }^{\circ} \mathrm{C}$ resulted in a $52 \%$ increase and a $25 \%$ decrease in TSH $\beta$ mRNA expression respectively, compared with the control (Fig. 4). In the pituitary cell culture of the European eel, it was demonstrated that treatment with $\mathrm{T}_{3}$ or $\mathrm{T}_{4}$ at $10^{-8} \mathrm{M}$ for 14 days at $18{ }^{\circ} \mathrm{C}$ resulted in a $70 \%$ decrease in TSH $\beta$ mRNA expression compared with the control (Pradet-Balade et al. 1997). We have also shown that after treatment of the bighead carp pituitary fragments with TRH and $\mathrm{T}_{4}$ at $10^{-8} \mathrm{M}$ for $36 \mathrm{~h}$ at $20^{\circ} \mathrm{C}$, the TSH $\beta$ mRNA expressions were $75 \%$ higher and $40 \%$ lower, respectively, than the control (Chatatterjee et al. 2001). The findings of these studies demonstrated that the in vitro response of TSH $\beta$ mRNA expression to TRH or thyroid hormones varied with different incubation conditions of the pituitary, such as tissue or cell culture, incubation temperature and time length, and other factors. In mammalian studies, it has been demonstrated that TRH stimulates TRH production by effects at the transcriptional and secretory levels. The TRHresponse regions have been identified in the TSH $\beta$ subunit gene promotor (Sarapura et al. 1995). It has also been established in mammals that TSH $\alpha$ and 


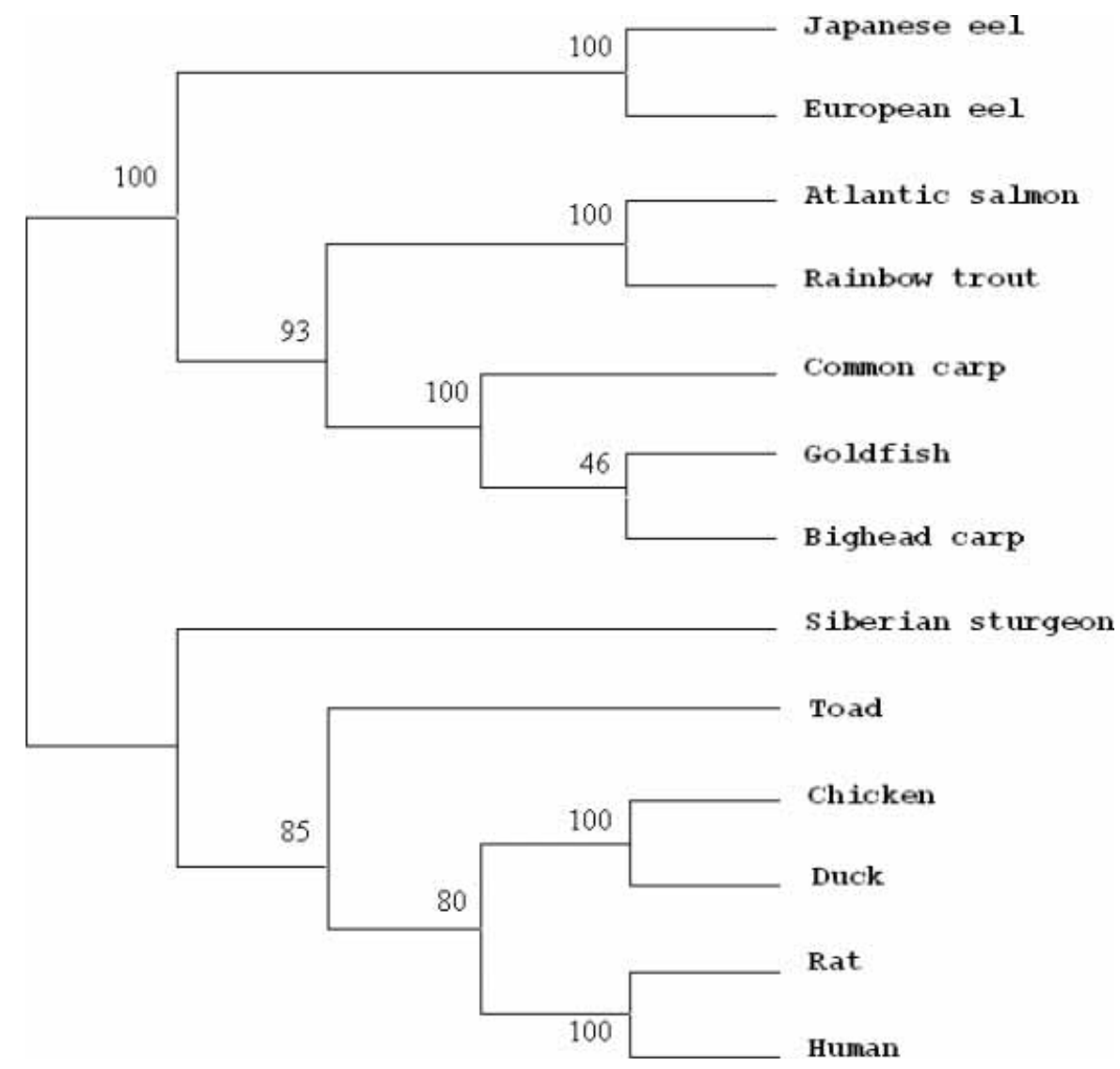

Figure $9 \mathrm{~A}$ phylogenetic tree of the putative mature peptide sequences of the TSH $\beta$ subunits from teleosts and selected species of tetrapods. The tree was constructed with the Neighbor-Joining method by the MEGA 2 program. The numbers indicate the bootstrap robustness from 1000 replicates. The top sequence of the $A$. japonica was from this study, and those of other sequences were from published papers and the accession numbers of the GenBank as indicated in the legend to Fig. 8.

TSH $\beta$ subunit genes contain thyroid response elements that mediate their transcriptions by the thyroid hormone-receptor complex (Chin et al. 1993). A thyroid-response element was also identified in the $\alpha$ subunit gene of Chinook salmon (Suzuki et al. 1995). Thus, the specific mechanism whereby TRH and thyroid hormones regulate TSH mRNA expression in teleosts is likely to resemble that found in mammals.

As indicated in the present study, the steady-state TSH $\beta$ mRNA levels in the pituitaries were increased with advancement of the silvering process. Such patterns were in parallel with the increasing levels of serum thyroxine. Since the quantification of TSH in teleosts is not available yet, the TSH levels in the pituitary and in the circulation remain unknown. The steady-state TSH $\beta$ mRNA levels estimated in the pituitaries may reflect TSH formation activity. Thus, the increased $\mathrm{TSH}$ formation in the pituitary during the eel silvering process leads to increased formation and release of thyroxine from thyroid tissues. In mammals, regulation of TSH gene expression, formation and secretion is well established (Sarapura et al. 1995). The formation and secretion of pituitary TSH is up-regulated by hypothalamic TRH and down-regulated by thyroid hormones via feedback mechanisms (Sarapura et al. 1995). However, TSH is also regulated by other hormones secreted from the hypothalamus and other tissues, e.g. somatostatin, dopamine, glucocorticoids (Sarapura et al. 1995, Schwartz 2000). Thus 
the regulation of TSH appears to be highly complex.

In Anguilla australis, injection of androgen (11-ketotestosterone) into females is found to induce some silvering-related morphological changes (Rohr et al. 2001). In the Japanese eel, the morphological changes, such as silver skin and dark pectoral fins, enlarged eyes, and degenerative digestive tract, are found to be synchronous with gonadal development during the silvering process (Han et al. 2003b), and the mRNA expression of both gonadotropin I $\beta$ and gonadotropin II $\beta$ is significantly higher in the silver stage compared with the yellow stage (Han et al. 2003a). When the freshwater-reared yellow Japanese eels were induced to become silver eels by repeated injection of human chorionic gonadotropin (hCG), similar morphological and physiological changes were observed (YS Han, WN Tzeng and IC Lia, unpublished data). All this evidence indicated that the gonadotropin and sex steroids play an important role during eel silvering. In female rainbow trout, the increase in the gonadosomatic index was greater when the fish were treated with $\mathrm{T}_{3}$ and gonadotropin in combination than when treated with gonadotropin alone ( $\mathrm{Cyr} \&$ Eales 1988). In the thecal cell culture of brook trout ovary, treatment with gonadotropin plus $\mathrm{T}_{3}$ caused a more significant increase in testosterone than treatment with gonadotropin alone (Cyr \& Eales 1996). Thus, thyroid hormones are undoubtedly involved in synergizing with gonadotropin during oocyte maturation. The existence of a thyroid hormone receptor in the gonad has also been proved in several teleosts such as perch (Chakraborti et al. 1986) and medaka (Soyano et al. 1993). This permits the enhancement of thyroid hormone on gonadotropin action. In the present study, the silvering eels were in the early gonadal development stage (Table 1). The higher activity of the pituitary-thyroid axis may synergize with the pituitary-gonad axis, as in other teleosts, to promote ovarian development during eel silvering.

In the wild arctic char, the blood thyroxine concentration is twice as high in upstream and downstream migrants as in non-migrants (Høgåsen \& Prunet 1997), and the underyearling sockeye salmon shows a natural surge in $\mathrm{T}_{4}$ before downstream migration occurs (Boeuf 1994). Thyroid hormone treatment could change the swimming direction of chum salmon fry to downstream (Boeuf 1994, Iwata 1995). Our previous study also found that, during silvering, the Japanese eel migrated from freshwater to seawater (Han et al. 2003c). As indicated in the present study, the expression of TSH $\beta$ mRNA was increased significantly (Fig. 6), in parallel to that of serum $\mathrm{T}_{4}$ levels during silvering of female eels (Fig. 7). Accordingly, the more active HPT axis in silver female eels might also be related to the downstream migration behavior of the silver eels.

When the freshwater-reared yellow Japanese eels were induced to become silver eels by injection of hCG, the appearance of the silver color seems to be later in hCG-induced eels than in the wild eels (YS Han, WN Tzeng and IC Lia, unpublished data). This implies that some other factors may also be involved in the body silvering of the eels in addition to hormones of the hypothalamus-pituitary-gonad (HPG) axis. In the masu salmon, thyroid hormone treatment could promote guanine deposition in the skin during bodily silvering in smoltification (Ikuta et al. 1985, Ura et al. 1994). In the European eel, the dispersal of purines in the skin was thought to cause a silver color on the belly of silver stage eels (Pankhurst \& Lythgoe 1982). These findings suggest that thyroid hormones may synergize with the HPG axis in causing silver skin coloration during the silvering process of the Japanese eel.

In conclusion, we have cloned both cDNA and genomic DNA of the TSH $\beta$ subunit of Japanese eel. The transcript levels of TSH $\beta$ mRNA were increased during eel silvering, and were parallel with the increased serum thyroxine levels. These results suggest that the HPT axis may play a role in the silvering process of the Japanese eel.

\section{Acknowledgements}

This study was financially supported by the Council of Agriculture, Executive Yuan, Taiwan, ROC (90AS - $1 \cdot 4 \cdot 5-\mathrm{FA}-\mathrm{F} 1-36$ and 91AS -2:5・1-FA-F1-8). The authors are grateful to Mr G H Cheng for sample collection and to $\mathrm{Mr} \mathrm{J} \mathrm{T} \mathrm{He}$ for gonadal histology.

\section{References}

Batten TFC, Moons L, Cambre ML, Vandersande F, Seki T \& Suzuki M 1990 Thyrotropin-releasing hormone immunoreactive systems in the brain and pituitary gland of the sea bass 
(Dicentrachus labrax, Teleosti). General and Comparative Endocrinology 79 385-392.

Boeuf G 1994 Salmonid smolting: a pre-adaptation to the oceanic environment. In Fish Ecophysiology, pp 105-135. Eds JC Rankin \& FB Jensen. London: Chapman and Hall.

Buckbinder L \& Brown DD 1993 Cloning and developmental expression of Xenopus laevis prolactin and thyrotropin genes. PNAS $903820-3824$.

Carr FE, Need LR \& Chin WW 1987 Isolation and characterization of the rat thyrotropin beta-subunit gene: differential regulation of two transcriptional start sites by thyroid hormone. Fournal of Biological Chemistry 262 981-987.

Chakraborti P, Maitra G \& Bhattacharya S 1986 Binding of thyroid hormone to isolated ovarian nuclei from a freshwater perch, Anabas testudineus. General and Comparative Endocrinology 62 239-246.

Chatterjee A, Hsieh YL \& Yu JYL 2001 Molecular cloning of cDNA encoding thyroid stimulating hormone $\beta$ subunit of bighead carp, Aristichthys nobilis and regulation of its gene expression. Molecular and Cellular Endocrinology 174 1-9.

Chin WW, Carr FE, Burnside J \& Darling DS 1993 Thyroid hormone regulation of thyrotropin gene expression. Recent Progress in Hormone Research 48 393-414.

Croyl ML \& Maurer RA 1984 Thyroid hormone decreases thyrotropin subunit mRNA levels in rat anterior pituitary. DNA 3 231-236.

Cyr DG \& Eales JG 1988 The influence of thyroidal status on ovarian function in rainbow trout, Salmo gairdneri. Fournal of Experimental Zoology 248 81-87.

Gyr DG \& Eales JG 1996 Interrelationships between thyroidal and reproductive endocrine systems in fish. Reviews in Fish Biology and Fisheries 6 165-200.

Gorbman A, Dickhoff WW, Vigna SR, Clark NB \& Ralph CL 1983 The thyroid gland. In Comparative Endocrinology, pp 185-275. Eds A Gorbman, WW Dickhoff, SR Vigna, NB Clark \& CL Ralph. USA: John Wiley \& Sons Inc.

Gregory CC \& Porter TE 1997 Cloning and sequence analysis of a cDNA for the beta subunit of chicken thyroid-stimulating hormone. General and Comparative Endocrinology 107 182-190.

Hamano K, Inoue K \& Yanagisawa T 1990 Immunohistochemical localization of thyrotropin releasing hormone in the brain of carp, Cyprinus carpio. General and Comparative Endocrinology 80 85-92.

Han YS, Liao IC, Huang YS, Tzeng WN \& Yu JYL 2003a Profiles of PGH- $\alpha$, GTH I- $\beta$, and GTH II- $\beta$ mRNA transcript levels at different ovarian stages in the wild female Japanese eel Anguilla japonica. General and Comparative Endocrinology 133 8-16.

Han YS, Liao IC, Huang YS, He JT, Chang CW \& Tzeng WN $2003 b$ Synchronous changes of morphology and gonadal development of silvering Japanese eel, Anguilla japonica. Aquaculture $219783-796$.

Han YS, Yu JYL, Liao IC \& Tzeng WN 2003c Salinity preference of the silvering Japanese eel, Anguilla japonica: evidence from the pituitary prolactin mRNA levels and otolith strontium/calcium ratios. Marine Ecology Progress Series 259 253-261.

Hayashizaki Y, Miyai K, Kato K \& Matsubara K 1985 Molecular cloning of the human thyrotropin-beta subunit gene. FEBS Letters $188394-400$.

Høgåsen HR \& Prunet P 1997 Plasma levels of thyroxine, prolactin, and cortisol in migrating and resident wild arctic char, Salvelinus alpinus. Canadian Fournal of Fisheries and Aquatic Sciences $\mathbf{5 4}$ 2947-2954.

Hsieh YL, Chatterjee A, Lee G \& Yu JYL 2000 Molecular cloning and sequence analysis of the cDNA for thyroid-stimulating hormone $\beta$ subunit of muscovy duck. General and Comparative Endocrinology 120 336-344.

Ikuta K, Aida K, Okumoto N \& Hanyu I 1985 Effects of thyroxine and methyltestosterone on smoltification of masu salmon (Oncorhynchus masou). Aquaculture 45 289-303.
Ito M, Koide Y, Takamatsu N, Kawauchi H \& Shiba T 1993 cDNA cloning of the beta subunit of teleost thyrotropin. PNAS $\mathbf{9 0}$ $6052-6055$.

Iwata M 1995 Downstream migratory behavior of salmonids and its relationship with cortisol and thyroid hormones: a review. Aquaculture 135 131-139.

Lokman PM \& Young G 1998a Gonad histology and plasma steroid profiles in wild New Zealand freshwater eels (Anguilla dieffenbachia and $A$. australis) before and at the onset of the natural spawning migration. I. Females. Fish Physiology and Biochemistry 19 325-338.

Lokman PM \& Young G 1998 b Gonad histology and plasma steroid profiles in wild New Zealand freshwater eels (Anguilla dieffenbachia and $A$. australis) before and at the onset of the natural spawning migration. II. Males. Fish Physiology and Biochemistry 19 339-347.

Matz SP \& Takahashi TT 1994 Immunohistochemical localization of thyrotropin releasing hormone in the brain of Chinook salmon (Oncorhynchus tsharoyscha). Journal of Comparative Neurology 345 214-223.

McNabb FMA 1992 Thyroid Hormones. New Jersey: Prentice-Hall Inc, Englewood Cliffs.

Morrison TB, Weis JJ \& Wittwer CT 1998 Quantification of low copy transcripts by continuous SYBR Green 1 monitoring during amplification. BioTechniques $24954-962$.

Pankhurst NW \& Lythgoe JN 1982 Structure and colour of the integument of the European eel, Anguilla anguilla (L.). Fournal of Fish Biology 21 279-296.

Paradet-Balade B, Schmitz M, Salmon C, Dufour S \& Quérat B 1997 Down regulation of TSH subunit mRNA levels by thyroid hormones in the European eel. General and Comparative Endocrinology 108 191-198.

Paradet-Balade B, Salmon C, Hardy A \& Quérat B 1998 Heterogeneity of eel thyrotropin BmRNAs is due to a minisatellite in the 3' untranslated region of the gene. Gene 215 251-257.

Pierce JG \& Parsons TF 1981 Glycoprotein hormones: structure and function. Annual Review of Biochemistry 50 465-495.

Prasad C 1985 Thyrotropin releasing hormone. In Handbook of Neurochemistry, vol 8, pp 175-200. Ed. L Abel. New York: Plenum Press.

Quérat B, Sellouk A \& Salmon C 2000 Phylogenetic analysis of the vertebrate glycoprotein hormone family including new sequences of sturgeon (Acipenser baeri) beta subunits of the two gonadotropins and the thyroid-stimulating hormone. Biology of Reproduction $\mathbf{6 3}$ 222-228.

Rohr DH, Lokman PM, Davie PS \& Young G 2001 11-Ketotestosterone induces silvering-related changes in immature female short-finned eels, Anguilla australis. Comparative Biochemistry and Physiology 130A 701-714.

Sarapura VD, Samuels MH \& Ridgway CE 1995 Thyroid stimulating hormone. In The Pituitary, pp 187-229. Ed. S Melmed. Malden. Massachusetts: Blackwell Science Inc.

Schwartz J 2000 Intercellular communication in the anterior pituitary. Endocrine Reviews 21 488-513.

Sohn YC, Yoshiura Y, Suetake H, Kobayashi M \& Aida K 1999 Isolation and characterization of the goldfish thyrotropin beta subunit gene including the 5 '-flanking region. General and Comparative Endocrinology 115 463-473.

Soyano K, Saito T, Nagae M \& Yamauchi K 1993 Effects of thyroid hormone on gonadotropin-induced steroid production in medaka, Oryzias latipes, ovarian follicles. Fish Physiology and Biochemistry 11 265-272.

Suzuki K, Dong L \& Hew CL 1995 A gene encoding Chinook salmon (Oncorhynchus tshawytscha) gonadotropin $\alpha$ subunit: gene structure and promotor analysis in primary pituitary cells. Molecular Marine Biology and Biotechnology 4 10-19.

Tesch FW 1977 The Eel. Biology and Management of Anguillid Eels. London: Chapman and Hall. 
Tzeng WN, Han YS \& He JT 2002 The sex ratios and growth strategies of wild and captive Japanese eels, Anguilla japonica. In Developments in Understanding Fish Growth. International Congress on the Biology of Fish, pp 25-42. Eds B Small \& D MacKinlay.

Vancouver: University of British Columbia.

Ura K, Hara A \& Yamauchi K 1994 Serum thyroid hormone, guanine and protein profiles during smoltification and after thyroxine treatment in the masu salmon, Oncorhynchus masou. Comparative Biochemistry and Physiology 107A 607-612.
Yamamoto K, Oomori M \& Yamauchi K 1974 Oogenesis of the Japanese eel. Bulletin of the Fapanese Society of Scientific Fisheries 40 9-15.

Yamano K, Tagawa M, de-Jesus EG, Hirano T, Miwa S \& Inui Y 1991 Changes in whole body concentrations of thyroid hormones and cortisol in metamorphosing conger eel. Fournal of Comparative Physiology 161B 371-375.

Received in final form 15 August 2003 Accepted 17 September 2003 